\begin{tabular}{|l|lll|}
\hline & PORT-SAID ENGINEERING RESEARCH JOURNAL \\
\hline
\end{tabular}

\title{
Effects of Indoor Environmental Quality on Occupant's Satisfaction, Health and Productivity
}

\author{
Hussein El-Salamouny ${ }^{1}$, Amal A. Abdou ${ }^{2}$, Mahmoud Ghoneem ${ }^{3}$
}

\begin{abstract}
Occupant satisfaction with indoor environmental quality (IEQ) in office buildings has been completely related to selfestimated job performance and, probably, to overall company productivity. Poor indoor environmental circumstances can negatively affect occupants' physical health through poor air quality, extreme temperatures, excess humidity, or insufficient ventilation and psychological health through inadequate lighting, acoustics, and ergonomic design. Sustainable or green building rating systems is attempting to address IEQ and occupant health concerns by providing healthier building environments. Although many qualitative studies claimed that improved IEQ also improves health and productivity and has provided substantial motivation to build green, quantitative studies are needed to prove these relationships. This research shows an outline of the results from a post occupancy evaluation (POE) study on indoor environment, occupant health, and wellbeing in two office buildings in greater Cairo: conventional building and green building certified using the Leadership in Energy and Environmental Design (LEED) Rating System; which is owned and occupied by the same origination. Evaluation of IEQ is based on 'Building Use Studies' (BUS) occupant questionnaire which applied in both buildings. This research highlighted that occupants productivity in office buildings can be enhanced through good building design, and provision of a high quality, healthy, and functional interior environment, that takes consideration of basic occupant needs.
\end{abstract}

Keywords: Indoor Environmental quality; Occupant Satisfaction; Post-Occupancy Evaluation; Productivity.

\section{INTRODUCTION}

Green Building movement gained further wide-scale acceptance with the development of marketable green certification systems such as Leadership in Energy and Environmental Design (LEED) which provides guidance for development of sustainable design, construction strategies and award certification for utilizing such strategies, thus considering the buildings as green. Sustainable or Green architecture, are terms used to describe "buildings that are minimizing the use of resources, reduce harmful effects on the ecology, create better environments for occupants, improve indoor air quality, and reduce building impacts on human health and the environment and encouraging a sense of well-being." [1].

One of the most significant benefits of green buildings is improving indoor environmental quality (IEQ). The term IEQ most commonly refers to a mixture of factors such as: air quality, thermal comfort, lighting, and acoustic conditions result mainly from design decisions and building operation procedures. A variety of building design and operational strategies affect IEQ, which in turn affects various human response factors: occupant comfort, well-being, health, and productivity [1].

${ }^{I}$ Teaching Assistant, Dept. of Architecture, Faculty of Fine Arts, Helwan University, Cairo, Egypt,

Email: hussein_salamouny@f-arts.helwan.edu.eg

${ }^{2}$ Professor, Dept. of Architecture, Faculty of Fine Arts,

Helwan University, Cairo, Egypt

${ }^{3}$ Associate Professor, Dept. of Architecture, Faculty of Fine Arts, Helwan University, Cairo, Egypt
The benefits of improving IEQ are immediately obvious when one considers two factors. First, it's been estimated that people spend approximately $90 \%$ of their time indoors [2]. It means that IEQ can have a potentially important effect on various human factors [3]. Therefore, the health risks may be greater due to exposure to indoor air pollution than that of the outdoor.

Secondly, the major goal in office building is to establish comfort environment, which may maximize human productivity .From economic aspect, Cost of energy saving or energy operating costs are sometime much smaller than that of productivity loss. Various sources estimate that $90 \%$ of the costs of a building are associated with employees' salaries, compared to only $9 \%$ being associated with owning and maintaining the building[4].

As green building movement became more frequent, evaluating the design intentions is significant . For decades Post-Occupancy Evaluation (POE) has been one of the strategic implementations of analysis on building sustainability after occupancy. POE has been defined by Zimring \& Reizenstein [5] as examination of the effectiveness for human users of occupied design environment. . Among the benefits gathered from POE is that it helps to identify successful design features to be repeated [6], identify problems to mitigate or reduce, improve building environment and performance [7], fine tune completed buildings, identify redundant or unnecessary building features and empower users to negotiate building issues and others. 
In order to create better indoor environment for the future, which not only expected, but take full advantage of all the changes that are taking place, it is important to have a comprehensive POE method, one that includes assessments of occupant well-being and productivity, completes the feedback loop that is essential for the successful future development and improvement of building design and practices.

\section{IMPORTANCE OF INDOOR ENVIRONMENTAL QUALITY AND OCCUPANT WELL-BEING}

Reducing buildings' energy consumption is the strongest factor for green buildings [8]. Most of green building rating systems provide the highest rating credits for reducing energy consumption. Indoor Environmental Quality (IEQ) is usually less emphasized in green building rating systems despite it's the relevant area of the Green accreditation process that relates to well-being and productivity [9].This is also despite the fact that In devoped countries people spend approximately 90 percent of their time indoors (U.S. Environmental Protection Agency \& the U. S. Consumer Product Safety Commission 2004), making them more prone to health risks due to exposure from indoor air pollutants [8]. Indoor Environmental Quality (IEQ) problems are not limited to one type of buildings as poor IEQ can negatively affect the health, productivity, and wellbeing of occupants in any of these buildings. Wargocki et al. [10] found a relationship between poor IEQ conditions and Sick Building Syndrome (SBS), and between good IEQ and improved health and productivity. Sullivan et al. [11] showed how improving buildings' IEQ increased occupant satisfaction and performance. Mendell \& Heath, G. A. [12] found that poor indoor environmental conditions can have adverse effects on their well-being and their performance in general. In addition to could cause dizziness, throat irritations, and other health problems which could in turn lead to decreased occupant satisfaction, and productivity [13]. Even though these studies seem to establish a relationship between IEQ and occupant well-being, there is a need for a more in-depth investigation of these issues [14]. The investigation of these issues is complicated by how difficult it can be to quantify the value of improved occupant health and productivity and resulting costs or cost savings [15].

One of the most popular green rating systems developed to date is the LEED system, established by the U.S. Green building Council (USGBC) in 1998 as a voluntarily US national standard for developing green commercial buildings [16] Since its foundation, the system has proven to be a popular choice for certifying new and existing green buildings [17]. Although there are claims to the improved IEQ of green buildings certified using this and other systems, there is little empirical evidence in the literature to substantiate such claims.

\section{INDOOR ENVIRONMENTAL QUALITY FACTORS}

Indoor Environmental Quality (IEQ) refers to the quality of a building's environment in relation to the health and well-being of its occupants, and includes aspects of design, analysis, and operation that lead to energy efficient, healthy, and comfortable buildings [18]. In this research, it specifically refers to the measured parameters of four main aspects: thermal comfort, indoor air quality, lighting quality and acoustic quality.

Thermal comfort is defined as that condition of mind which expresses satisfaction with the thermal environment [19]. It was identified that when 80 percent of the building occupants were satisfied with the surrounding thermal conditions, the thermal environment is then in a satisfactory condition [20]. Parameters such as temperature, humidity, and air flow are take into consideration to recognize the thermal comfort level in particular zone [21].

Indoor Air Quality (IAQ) refers to thermal conditions that can affect occupants' health and well-being. Health threats such as headache, fatigue, respiratory problems, and irritations or allergies of nose, eyes, and throat may arise when the air consisting of pollutants such as biological contaminants such as mould, radon, carbon monoxide and formaldehyde [22].

Research undertaken by Veitch [23] recognizes that lighting quality is more than just providing an appropriate quantity of light. Several aspects contribute to lighting quality such as illuminance, luminance distributions, light color characteristics and glare

According to Kim and Haberl [24], acoustic quality is studied to pinpoint the sound or vibration isolation and the level of noise from background. It is based on a number of parameters such as reverberation time, sound insulation and background noise [25].

\section{METHODS}

\subsection{Sample Selection}

This research is studying a LEED certified office building and its previous accommodation building. The buildings will be referred to as Building A and Building B. The names of the buildings were omitted for confidentiality purposes. The two sample office buildings are located in Greater Cairo, Egypt. Both buildings are operated by the same owner which is an engineering and architectural firm. Building A is a LEED NC Gold certified building while Building $\mathrm{B}$ is a conventional office building. It should be noted that occupants have been working in Building $\mathrm{B}$ before they move to the new workspace Building A. Table 1 summarizes the main features of the two office building selected. The operator of the two studied buildings is an international engineering and architectural firm, which consolidating all of its offices currently scattered throughout Cairo. 
Table 1: Summary of the main features of the two office building selected

\begin{tabular}{|l|c|c|}
\hline Building Features & Building A & Building B \\
\hline $\begin{array}{l}\text { Year of } \\
\text { completion }\end{array}$ & 2014 & 1995 \\
\hline $\begin{array}{l}\text { Total Building } \\
\text { Floor Area (m2) }\end{array}$ & 42,300 & 12,800 \\
\hline No. of floors & $\begin{array}{c}\text { 5 Floors and 3 } \\
\text { Basements }\end{array}$ & $\begin{array}{c}\text { 8 Floors and 1 } \\
\text { Basement }\end{array}$ \\
\hline $\begin{array}{l}\text { Air-conditioning } \\
\text { system }\end{array}$ & $\begin{array}{c}\text { Mechanical } \\
\text { Ventilation }\end{array}$ & Mixed Mode \\
\hline Glazing system & About 85\% & About 50\% \\
\hline Green rating & LEED NC Gold & Not certified \\
\hline
\end{tabular}

\subsection{Occupant Survey (BUS Method)}

The BUS questionnaire is a self-reporting method of PostOccupancy Evaluation (POE) developed in 1985 by Adrian Leaman of BUS Ltd [26]. This method has been developed in 1995 when it was applied to a series of government funded building performance evaluation studies in the UK [27]. This questionnaire has been developed from the original 16 page BUS Office Environment Survey version to their present 3 page version, which was used for this research. The BUS questionnaire was used to explain the limitations of current questionnaires in measuring perceived indoor envronmental factors. The use of this questionnaire was necessary as it is a popular method of measuring the effect of IEQ on occupant satisfactions and productivity through self-report. It is applied internationally and its results have been used extensively in this area of research. The questionnaire contains questions which are concerned with office environmental performance and operational matters. It uses a structured Likert scale of 1-7 over 45 key variables evaluated in the questionnaire. While the questionnaire was designed to capture the overall perception of a building, only sections addressing IEQ and productivity were considered in this research.

The 45 questions include IEQ parameters and BD\&FM factors [28] as shown in Table 2. IEQ factors amend questions about temperature in winter and summer, acoustic quality, and lighting. The BD\&FM parameters got opinions about building image, design, space, fit-out, cleaning, the availability of meeting rooms and storage, occupant health, well-being and behaviour, and response to problems. Baird and Thompson have included a more detailed description and the full text of the BUS surveys [29].
Table 2: Survey questionnaire structure and format detail

\begin{tabular}{|c|c|c|}
\hline Elements & $\begin{array}{c}\text { Survey } \\
\text { Satisfaction } \\
\text { Category }\end{array}$ & Aspects \\
\hline \multirow{5}{*}{$\begin{array}{l}\text { IEQ (Indoor } \\
\text { Environment } \\
\text { Quality) }\end{array}$} & $\begin{array}{l}\text { Temperature in } \\
\text { summer }\end{array}$ & $\begin{array}{l}\text { Thermal comfort, } \\
\text { thermal sensation, } \\
\text { and temperature } \\
\text { stability }\end{array}$ \\
\hline & $\begin{array}{l}\text { Temperature in } \\
\text { winter }\end{array}$ & $\begin{array}{l}\text { Thermal comfort, } \\
\text { thermal sensation, } \\
\text { and temperature } \\
\text { stability in your } \\
\text { workplace }\end{array}$ \\
\hline & Air quality & $\begin{array}{l}\text { Air quality (stillness, } \\
\text { dryness, freshness, } \\
\text { odours, and overall } \\
\text { satisfaction) }\end{array}$ \\
\hline & Lighting & $\begin{array}{l}\text { Amount of light } \\
\text { (overall, natural light, } \\
\text { artificial light, glare } \\
\text { from sky and sun, } \\
\text { glare from artificial } \\
\text { lights) }\end{array}$ \\
\hline & Acoustics & $\begin{array}{l}\text { Noise (overall, noise } \\
\text { from colleagues, } \\
\text { noise from other } \\
\text { people, noise from } \\
\text { inside, noise from } \\
\text { outside, unwanted } \\
\text { interruptions) }\end{array}$ \\
\hline \multirow{5}{*}{$\begin{array}{l}\text { BD\&FM (Building } \\
\text { Design \& } \\
\text { Facilities } \\
\text { Management) }\end{array}$} & $\begin{array}{c}\text { The building } \\
\text { overall }\end{array}$ & $\begin{array}{l}\text { Building design, } \\
\text { needs, spaces, image, } \\
\text { safety, cleaning, } \\
\text { availability of } \\
\text { meeting rooms, } \\
\text { suitability of storage } \\
\text { arrangements, } \\
\text { furniture, space at } \\
\text { desk }\end{array}$ \\
\hline & Health & $\begin{array}{l}\text { The change on } \\
\text { general health }\end{array}$ \\
\hline & Productivity & $\begin{array}{l}\text { The change on } \\
\text { working productivity }\end{array}$ \\
\hline & $\begin{array}{l}\text { Effect on } \\
\text { behavior }\end{array}$ & $\begin{array}{l}\text { Change of behaviours } \\
\text { because of building } \\
\text { conditions }\end{array}$ \\
\hline & $\begin{array}{l}\text { Response to } \\
\text { problems }\end{array}$ & $\begin{array}{l}\text { Requests submitted } \\
\text { for maintenance and } \\
\text { operation of heating, } \\
\text { cooling, ventilation, } \\
\text { lighting }\end{array}$ \\
\hline
\end{tabular}

\subsection{Data Collection}

The BUS hard-copy survey was given to the occupants in the buildings, approximately one week before the physical measurements. Occupants were invited to take the survey by buildings' directors and divisions' managers.

The questionnaire was given to the occupant in the morning hours (9-10 am) of the day. A drop box was made available in each office reception wherein the answered questionnaires are to be dropped off. It was available to be collected from the office reception in the afternoon (3-4 pm). 
Although the invitation was emailed to the buildings' managers who forwarded the email invitation to participants themselves, the managers did not receive any of the survey responses and could not identify any of the occupants who had participated in it. Once filled in by the respondents, the data from the questionnaires are typed in to a pre-formatted Excel file, using a standard file format with fixed variable names and it sent to Building Use Studies. The survey building data files in Excel are then error and range checked. Excel files are readable by FileMaker Pro and Aabel (a statistical graphics package used for publication quality output), as well as being programmable by AppleScript. BUS's in-house analysis and data entry work is carried out using Apple OS, but with software which is cross- platform so that the approach can be replicated on other platforms if necessary.

\section{RESULTS AND DISCUSSION}

\subsection{Evaluation of Building in General}

With the view to evaluate each side of both Buildings performance like indoor environment, it was significant to put this in a wide context of the occupant's perceptions of the building altogether. Figure 1 shows a summary of Occupant Satisfaction with building design, image, and efficiency to provide a proper needs, with satisfaction scores for these aspects higher in Building A, which better than BUS benchmarks. This result is according to the BUS Summary Index, which is achieved from a selection of key variables in the employees' survey data. The occupants were asked to rate the overall building design. The results showed that most of the occupants in Building A were satisfied with the design of the building (87\%). The building scored higher than the BUS benchmark (5.4; 4.99 respectively). The majority of the respondents in Building B were also satisfied with the design of the building $(65 \%)$. The building scored less than the BUS benchmark (3.64; 4.99 respectively). The results showed that $95 \%$ of the occupants in Building A were satisfied with the image of the building. However, $68 \%$ were satisfied with Building image in Building B.

\section{Building Overall}

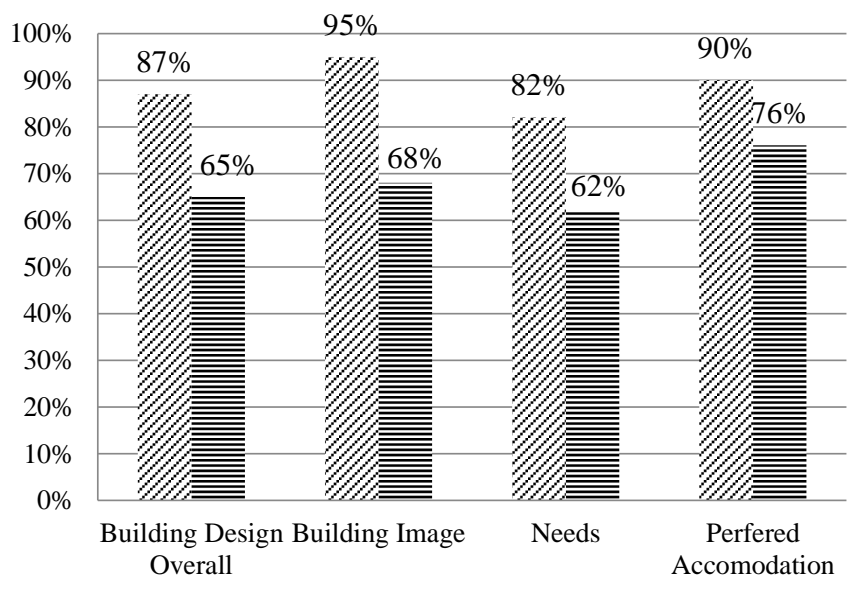

\& Building $\mathrm{A} \equiv$ Building $\mathrm{B}$

Fig. 1 Occupant satisfaction results for features according to both building

\subsection{Evaluation of Indoor Environment}

\section{Indoor Evironment Summary}

According to the survey results indoor air quality, thermal comfort, and overall comfort are rated more satisfied in Building $\mathrm{A}$ as indicated in Figure 2, with satisfaction ratings for pertinent features of about 81 percent, and all higher than BUS benchmarks. The results showed that most of the occupants in Building A were satisfied with the lighitng and acoustical quality and it was rated (75 percent), and are statistically near to the benchmarks scale.

Perceived control of indoor enviornment was rated not satifactory in Building A, but only some occupants pointed this as significant to them, and that is the reason why this study is not considered as a major parameter in evaluation of the indoor Environment.

To summarize IEQ in Building A, air quality and thermal comfort are very good, based on employees perceptions. Lighting quality and Acoustics quality are considered satisfactory only, because of the comparatively lower occupant satisfaction scores for these paramerters.

\section{Indoor Environment - Occupant Satisfaction Summary}

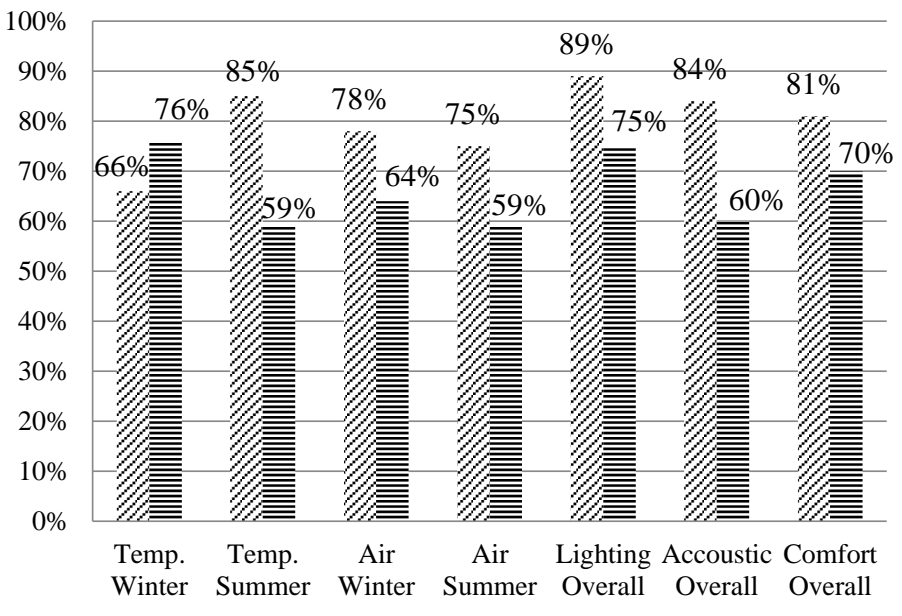

״ Building $\mathrm{A} \equiv$ Building $\mathrm{B}$

Fig. 2 Summary of occupant satisfaction according to parameters of indoor environmental quality

\section{Thermal Comfort and Air Quality}

For Building $\mathrm{A}$, the temperature in summer was rated comfortable $(85 \%)$ whereas the temperature in winter was rated uncomfortable (66\%). Air quality in summer was rated satisfactory $(75 \%)$, also the satisfaction rating for air in winter was high $(70 \%)$. The temperature in summer was observed as neither cold nor hot, and it is stable during the day. The temperature in winter was regarded as too cold, and it also varied during the day. The air in summer was noted as neither dry nor humid and mostly fresh and odourless. The air in winter was regarded as humid, neither still nor draughty and fresh and odourless. From these results, it can be observed that Building A did not perform well in the winter season, although the building is mechanical ventilated. With respect to the 
people $(85 \%)$ as well as unwanted interruptions (70\%). The noise from colleagues was regarded as normal. The respondents noted that the noise from outside was higher than normal, since the building is located near to the center of the city and mixed ventilated, requiring opened windows for air flow. Despite this, the building scored slightly lower than the benchmark $(4.15 ; 4.27)$.

There were 15 responses to noise in the respondents' work areas from the respondents in Building B. The responses were mostly negative (12), centering on the noise generated from outside the building. Responses like "very noisy when front sliders are open", "traffic outside sirens", "can hear a lot of noise if people outside tenancy are talking" were prevalent. Other responses like "it can be noisy depending on number of people; open plan office", "reverberation on hard surfaces" identified other sources of noise in the building. In the case of, the responses on noise were also mostly negative. Responses like "can hear voices, phones in adjoining offices quite clearly. Discussions on social bridge area carry clearly to my office", "partitions do not stop noise from adjoining offices particularly telephone cables" were prevalent. Satisfaction ratings with acoustics in both buildings are indicated by the questionnaire results shown in Figure 5 .

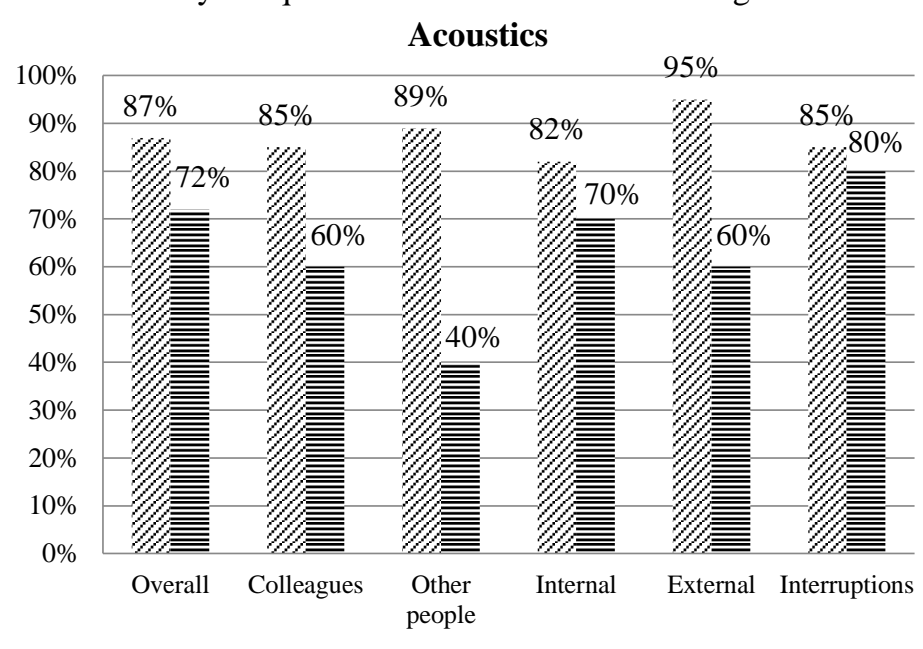

ஜ Building $\mathrm{A} \equiv$ Building $\mathrm{B}$

Fig.5: Summary of occupant satisfaction with Acoustics

\section{Facilities, Furnishings and Fit-out}

As shown in Figure 6, Building A occupants are highly satisfied with the building facilities, furnishings and fitout. Usability of workstations, the effectiveness of space use in the building, storage facilities, IT systems, availability of meeting rooms, and building facilities overall are all rated at more than eighty percent satisfaction and most of it is higher than BUS benchmarks. Satisfaction with the furniture of the office building is above $74 \%$. Occupant comments were very positive about the cycling and changing facilities. In contrast to the high satisfaction rating for meeting room availability, detailed comments by occupants indicated that access to private work area for confidential meetings can be an issue at times.

\section{Facilities \& Fitout}

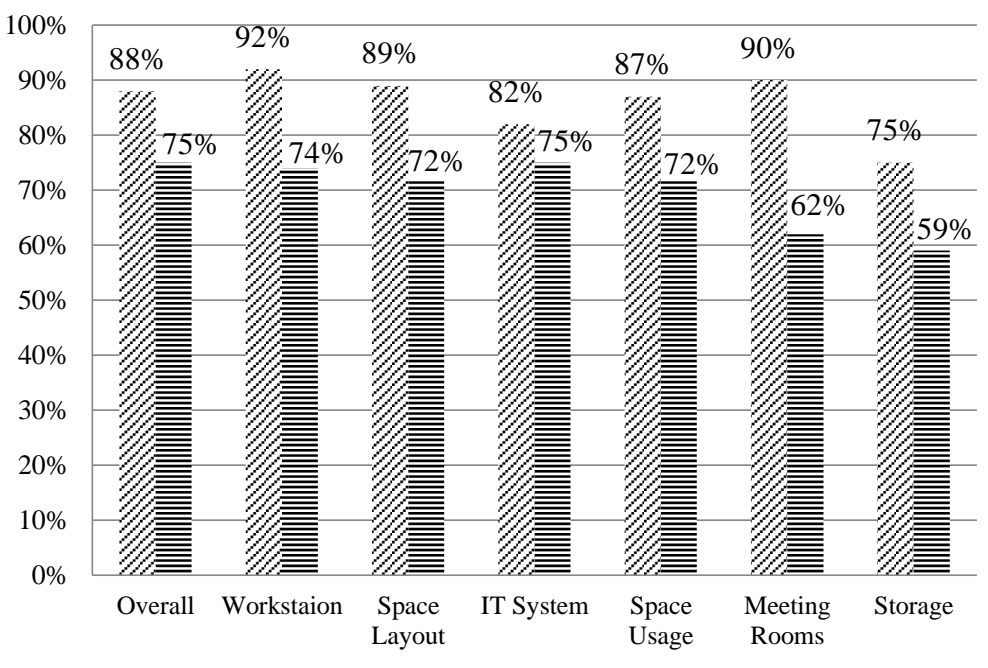

٪/Building A $\equiv$ Building B

Fig.6: Summary of occupant satisfaction with building facilities and fit-out

\subsection{Evaluation of Health, Well-being, and Productivity}

\section{Productivity}

According to the questionnaire results it was obvious that Building $\mathrm{A}$ has a big productivity instance comparing to Building B data. Figure 7 shows that $70 \%$ of Building A occupants have rated their building as getting a positive or neutral influence on productivity, compared with just $29 \%$ in Building B. According that turning that data into productivity gain or loss, as shown in Figure 8, it is evaluated that this could show a greater than $15 \%$ productivity and performance growth, according to the nine-point scale and evaluation method used in the BUS survey.

The occupants were asked to estimate how much they think their productivity at work is decreased or increased by the environmental conditions in the building. $62 \%$ of the respondents in Building A reported an increase in their productivity at work $(+10 \%$ to $+40 \%$ or more $), 30 \%$ reported a decrease $(-10 \%$ to $-40 \%$ or less), while $8 \%$ reported that their productivity had neither increased nor decreased $(0 \%)$. The close response rate between those that stated a positive increase and those which were neutral is in line with the response received for the question on perceived health. With this result, Building A attained a percentile of 84 , with a higher score mean than the benchmark $(13.47 ; 3.78)$.

In the case of Building B, twenty percent $(20 \%)$ of the respondents reported an increase in their productivity at work $(+10 \%$ to $+40 \%$ or more), $56 \%$ reported a decrease ( $-10 \%$ to $-40 \%$ or less) while $24 \%$ reported that their productivity had neither increased nor decreased $(0 \%)$. This result is in line with the one on Health. Building B attained a percentile of 87 , with a much higher mean score than the benchmark $(-6.33 ; 3.78)$.

The responses on productivity were somewhat different from the rating received. The respondents made comments such as "can't really say, but it is a lovely building to 
arrive to everyday", "not aware that this is affected". There were also responses that identified other factors which are not related to the indoor environment of the building as potential factors that influenced an increase in their productivity. These are evidenced in responses made such as "productivity, affected as much by other factors of people culture and work projects", "affected by colleagues". Some respondents stated that adapting to the environment has had an influence on their productivity. Responses that related to the building environment were centered on comfort rather than productivity with responses like "hard to work when you are freezing", "too cold in winter", "having the ability to have fresh air within the tenancy rather than ac modulated definitely better for productivity".

In Building B, the responses were in line with the ratings. The majority of the responses showed that the occupants did not think their productivity had been increased nor decreased by the environmental conditions in the building. The respondents gave answers such as "can't know if it affects productivity", which illustrates a lack of awareness of the effect of IEQ on productivity. Other comments from occupants indicate that air quality and building image were important for productivity and the open plan office layout has enhanced teamwork and communication.

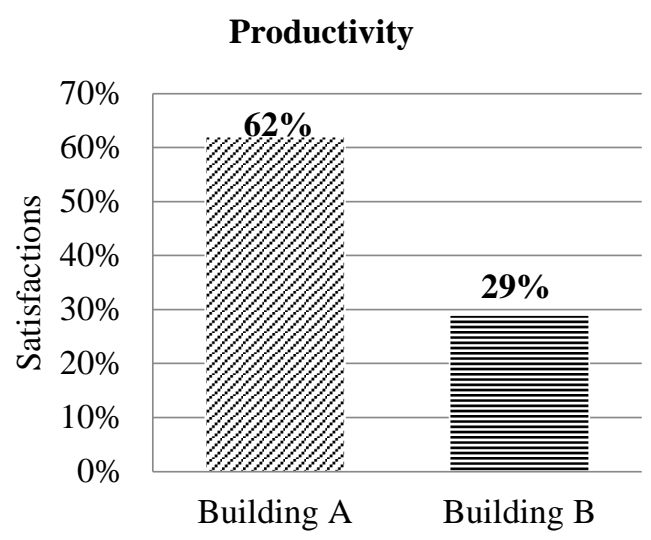

Fig.7: Proportion of occupants rating the building as positive or neutral for their perceived productivity

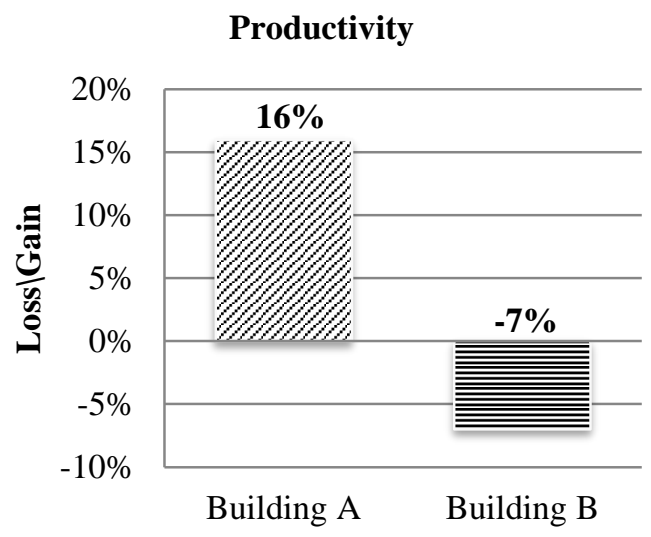

Fig.8: Estimated perceived productivity loss or gain for Building A and Building B

\section{Health and Wellbeing}

The occupants were asked the question "Do you feel less or more healthy when you are in the building?" The majority of the respondents in Building A stated that they did not feel less nor more healthy in the building $(28 \%)$. $26 \%$ felt they were more healthy, while $46 \%$ stated that they were less healthy in the building. This gave the building a percentile of 24 amongst buildings internationally. The building also scored lower than the benchmark $(3.6 ; 4.2)$.

In Building B, fifty-two per cent (52\%) of the respondents stated that they were more healthy; $22 \%$ stated otherwise and $26 \%$ stated that they were neither less nor more healthy in the building. This gives the building a percentile of 69 amongst buildings internationally. The building also scored higher than the benchmark (4.61; 4.2).

Responses on health in Building A were mostly negative. However, the quality of these responses described the preference of occupants in relation to previous buildings. The respondents complained of fumes that travel through air-conditioning, sore throat, headaches from glare and the stuffy environment .

\section{CONCLUSION}

Three objectives were set to test the adequacy of the BUS questionnaire. Firstly, to ascertain whether the occupants were comfortable and satisfied with the performance of each building, secondly, the questionnaire was used to assess the occupants' perception of the IEQ factors in each building; and thirdly, to assess and compare the differences in perceived productivity as a result of the IEQ in each building.

This study observed that the occupants of both buildings were satisfied with the building's performance. Although the claim that LEED certified office buildings can offer more comfortable environments to their occupants than other conventional buildings based on the sample studied in this research. The LEED certified office buildings in this research offered workspaces with better thermal comfort, indoor air quality, lighting quality and acoustics quality. The evidence provided in this research was based on subjective qualitative feedback from buildings' occupants about them.

The second component involved the administration of an occupant survey to occupants working in there. A survey was conducted to evaluate occupants' perception and satisfaction with their workspaces IEQ. The survey comprising a total of 45 questions enquired about occupants' demographics, their satisfaction with temperature and thermal comfort, lighting quality and acoustics quality.

The third objective of the research entailed evaluating IEQ in relation to occupant health, well-being and productivity in a LEED certified office building using BUS methodology. The resulet shows that occupants' preception of the LEED certifed building with health and well-being was unsatisfactory since most of occupants comment the absence of fresh air is the main reason of this concerns. 


\section{REFERENCES}

1. Bluyssen, P.M. The Indoor Environment Handbook: How to make buildings healthy and comfortable. London, UK. : Earthscan,, 2009.

2. Klepeis, Neil E., et al., et al. The National Human Activity Pattern Survey (NHAPS): A resource for assessing exposure to environmental pollutants. California , USA : Lawrence Berkeley National Lab., 2001. pp. 231252.

3. Clements-Crome. Creating the Productive Workplace. 2nd. New York : NY: Taylor \& Francis, 2006.

4. Browning, Bill. The Economics of Biophilia: Why designing with nature in mind makes sense. [Online] 2012.

https://www.lbhf.gov.uk/sites/default/files/section_attach ments/the_economics_of_biophilia_-

_why_designing_with_nature_in_mind_makes_financial_ sense.pdf. Last accessed $r \wedge$ Novermber 2018.

5. Zimring, C. and Reizenstein, J. E. Post-Occupancy Evaluation: An Overview in Environment and Behavior. 1980. pp. 429-451. Vol. 12.

6. Review of building quality using post occupancy evaluation. Watson, C. 2003, Journal of Programme Education, pp. 1-5.

7. Vischer, J. Post Occupancy Evalua. s.1. : Federal Facilities Council.US: The National Academy Press, 2002. pp. 23-34.

8. Different aspects of assessing indoor and outdoor thermal comfort. Hoppe, P. s.1. : 661-665, 2002. Energy and Buildings.

9. Abbaszadeh, S., et al., et al. Occupant satisfaction with indoor environmental quality in green buildings. Center for the Built Environment. 2006.

10. Wargocki, P., et al., et al. The effects of outdoor air supply rate in an office on perceived air quality, Sick Building Syndrome (SBS) symptoms and productivity. Indoor Air. 2000

11. Sullivan, J., Braid, G. and Donn, M. Measuring Productivity in the Office Workplace. Victoria: University of Wellington: Centre for Building Performance Research. 2013.

12. Mendell, M. J. and Heath, G. A. Do Indoor Pollutants and Thermal Conditions in Schools Influence Student Performance? A Critical Review of the Literature. Indoor Air. 2005.

13. Effects of Heat Stress on Cognitive Performance: The Current state of Knowledge. Hancock, P. A. and Vasmatzidis, I. 2003, International Journal of Hyperthermia.

14. Effects of green buildings on employee health and productivity. Singh, A., et al., et al. 2010, American Journal of Public Health.

15. Birkenfeld, B., et al., et al. Quantifying the Hidden Benefits of High-Performance Building. 2011.

16. USGBC. LEED Reference Guide for Green Building Design and Construction. Washington, DC: U.S. Green Building Council. 2009.
17. Issa, M. H., et al., et al. Detailed analysis of electricity, water, and gas consumption quantities and costs in Toronto's public schools. Canadian Journal of Civil Engineering. 2010, pp. 25-36.

18. NIOSH. INDOOR ENVIRONMENTAL QUALITY Workplace Safety and Health Topics: Center of Disease Control and Prevention. 2013.

19. Introduction to Thermal Comfort Standards and To the Proposed New Version of EN ISO 7730. Olesen, B. W. and Parsons, K. C. 6, 2002, Energy and Buildings, Vol. 34, pp. 537-548.

20. ASHRAE Standard . Standard 55-1992. Atlanta, GA: American Society of Heating, Refrigeration and AirConditioning Engineers. 1992.

21. - Standard 55-2004. Atlanta, GA: American Society of Heating, Refrigeration and Air-Conditioning Engineers. 2004.

22. Kubba, S. Handbook of Green Building Design and Construction: LEED, BREEAM, and Green Globes. s.l. : Butterworth-Heinemann, 2012. pp. 215-348.

23. Determinants of lighting quality I: State of the science. Veitch, J. A. and Newsham, G. R. 1, 1998, Journal of the Illuminating Engineering Society, Vol. 27, pp. 92-106.

24. Field-Test of the New ASHRAE/CIBSE/USGBC Performance Measurement Protocols: Intermediate and Advanced Level Indoor Environmental Quality Protocols. Kim, H. and Haberl, J. S. 2, 2012, ASHRAE Transactions, Vol. 118, pp. 58-65.

25. Objective and subjective evaluation of the acoustic comfort in classrooms. Zannin, P. H. T. and Marcon, C. R. 5, 2007, Applied Ergonomics, Vol. 38, pp. 675-680.

26. Leaman, Adrian . Usable Buildings. [Online] 2012. [Cited: 22 May 2017.] http://www.usablebuildings.co.uk.

27. Cohen, R., et al., et al. Assessing building performance in Use 1: the Probe process. Building Research and Information. 2001, Vol. 29, 2, pp. 85-102.

28. A comparison of the performance of sustainable buildings with conventional buildings from the point of view of the users. Baird, G., Leaman, A. and Thompson, J. 2002, Arch. Sci. Rev., Vol. 55, pp. 135-144.

29. An examination of the distribution of user perception scores in a world-wide set of sustainable buildings. Baird, G. and Thompson, J. Sydney, Australia : s.n., 2011. 44th Annual Conference of the Architectural Science Association (ANZAScA) University of Sydney. pp. 14-16. 


\section{تأثير جودة البيئة الداخلية على رضا الثـاغلين و الصحة و معدل الإنتاج لهم}

الملخص

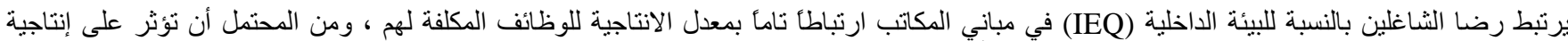

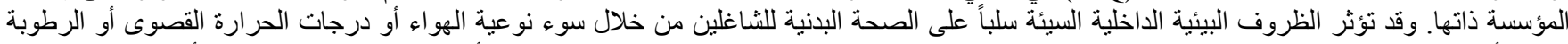

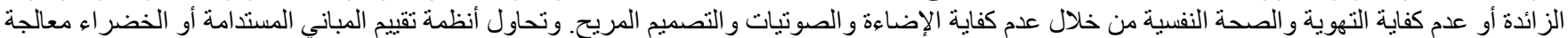

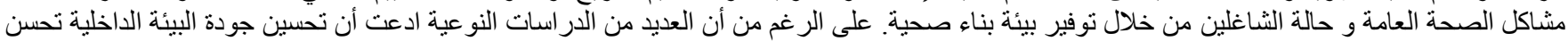

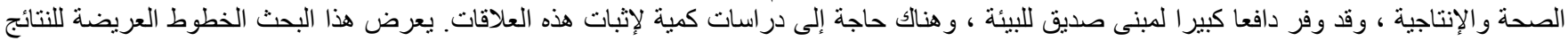

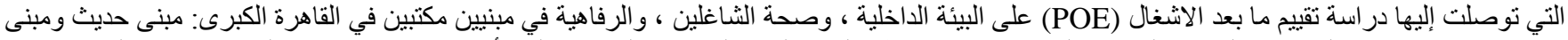

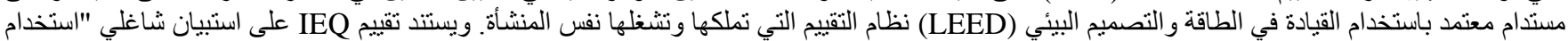

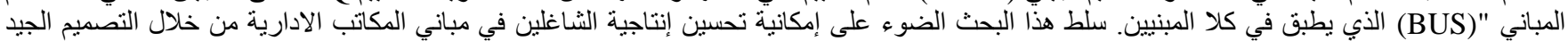

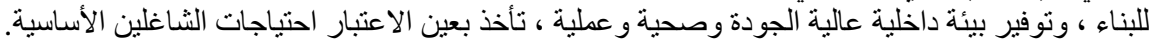

